\title{
Destination Branding: A Review of the City Branding Literature
}

\author{
Irisi Kasapi \\ Lecturer of Marketing \& Management, \\ Department of Business and Economics, \\ University of New York Tirana \\ Ariana Cela \\ Assistant Professor of Management, \\ Department of Business and Economics, \\ University of New York Tirana
}

Doi: $10.1515 / m j s s-2017-0012$

\begin{abstract}
While there exist studies which attempt to measure the brand equity of cities and countries from a customer perspective, there is little or no evidence regarding a thorough review of the destination branding literature from its inception to date, and more specifically about city branding. The objective of this study is thus to present a review of the literature of city branding, with the main aim of aiding tourism destination researchers who are conducting studies in this particular field. In order to conduct this review, ProQuest (ABI/INFORM) database was utilized, using the terms 'city branding' and 'destination branding' from 2005 through December 2016, as the review of the literature suggests the first traces of publications documenting 'city branding' studies appeared on 2005. This review serves as a roadmap for researchers in the field of destination branding, as it provides an overview of the concept of branding and its origins, a review of the concepts of place and destination branding who served then as an umbrella to the concept of city branding. Further, attention is devoted to summarizing the studies published on 'city branding', providing in this way a valuable contribution for the audience interested in the topic of destination branding, and more specifically its city-related subarea. In light of the review conducted, it is found out that the research field of city branding remains still in its infancy, suggesting that there is still room for further research in this particular area.
\end{abstract}

Keywords: branding, place branding, city branding, destination branding, review

\section{Introduction}

Branding is of a paramount importance when it comes to laying down the marketing strategy. Just as goods, services and organizations are branded. Moreover, cities can similarly be promoted. Cities own an array of features, such as culture, art, heritage, or natural resources that make up what De Chernatony and McDonald (1992:3) equates to 'complex identities that exist in the minds of consumers'. In the meantime, these features work together towards creating a differentiated image in the minds of consumers. Because a brand represents what exists in the minds of consumers and not what the marketer intends to present through the brand (de Chernatony and McDonald, 1992), this brief literature review will focus on the concepts of brand equity from a customer's perspective with the main aim of transferring any theoretical approach in the branding literature to a destination context. The premise of place branding, upon which "the principle that cities and regions can be branded" (Kemp et al., 2012, p. 508) is built, is further discussed in the 
paper. As a matter of fact, the branding concept has been only recently embraced by the tourism destination studies. Nevertheless since 1998, date when according to Pike (2008) the first destination branding articles started to flourish, the interest shown by scholars towards the destination branding concept has been growing. This demonstrates, in turn, that because the topic is investigated for less than two decades, the research field about destination branding remains in its infancy (Konecnik, 2014, p. 9).

But can destinations be branded like products, services, or organizations, and if yes, to what extent? This is an important question we will try to answer to through this brief review of the literature on the topic. Below we draw an interesting analogy Kavaratzis and Ashworth (2006:189) offered in their account 'City branding: An effective assertion of identity or a transitory marketing mix?'

"All branding tries to endow a product with a specific and more distinctive identity, and that is, in essence, what most city marketing seeks to do for cities. A place needs to be differentiated through a unique brand identity if it wants to be, first, recognized as existing, secondly, perceived in the minds of place customers as possessing qualities superior to those of competitors and, thirdly, consumed in a manner commensurate with the objectives of the place" (italics added)

\section{Methods}

When it comes to framing the review, one of the most popular approaches is being implemented, that of dividing the review into themes or categories. As of the nature of the review, this paper falls under the category of 'narrative overviews'. According to Gall et.al, 'narrative reviews' are, "emphasized better-designed studies, and organized their results to form a composite picture of the state of the knowledge on the problem or topic being reviewed. Each study may have been described separately in a few sentences or a paragraph" (as cited Randolph, 2009, p. 8-9). The main themes that have prevailed from the review of the literature are related to branding and its origins, place branding and destination branding, and finally city branding. In order to conduct this review, ProQuest (ABI/INFORM) database was utilized, using the terms 'city branding' and 'destination branding' from 2005 through December 2016.

\section{Discussion}

\subsection{Definition of a Brand}

To develop an understanding of the concept of destination branding and more specifically 'city branding', it is worth spending some time to review the concept of a brand, which fuels the whole idea behind this paper. As such, the most well-known and cited definition of a 'brand' is the one proposed by the American Marketing Association (1960), or as otherwise known as the companyoriented definition of a brand, according to which a brand is:

"A name, term, sign, symbol, or design, or a combination of them, intended to identify the goods or services of one seller or group of sellers and to differentiate them from those of competitors" (as cited on Wood, 2000, p. 664; italics added).

Although it has been considered as the starting point among all definitions of a 'brand', it has simultaneously drawn much criticism for being too product-oriented (Wood, 2000, p. 664). Modified versions of this definition, have however survived to these days (Waitkins, 1986; Aaker, 1991; Stanton et al., 1991; Doyle, 1994) (as cited on Wood, 2000, p. 664). In addition to this productoriented definition, a consumer-oriented definition has in turn been provided by Ambler (1992), as he defines a brand as:

"the promise of the bundles of attributes that someone buys and provide satisfaction . . The attributes that make up a brand may be real or illusory, rational or emotional, tangible or invisible" (italics added) 
Furthermore, according to Konecnik and Gartner, “... a brand can be treated as a legal instrument, logo, company, identity system, image, personality, relationship, and/or as adding value" (2007:400). We might find all these perspectives incorporated in the definition brought forth by De Chernatony and McDonald (2001:20), according to whom, a brand is:

"an identifiable product, service, person, or place, augmented in such a way that the buyer or user perceives relevant, unique added values which match their needs most closely [and] its success results from being able to sustain these added values in the face of competition" (as cited on Konecnik and Gartner, 2007, p. 400-01; italics added).

A few scholars however, agree on the premise that brands are not limited to signs or trademarks, but instead it provides what is known as a 'socio-psychological construct' of the definition of brands (Jacobsen, 2009, p. 73). In this respect, there is an agreement among various bodies of scholars that "the value of brands resides primarily in the mind of the consumer, not in the factory of the producer" (Anholt, 1999, p. 4), evoking a strong emotional tie with goods, services, persons, or places (Florek, 2005, p. 209) (as cited in Jacobsen, 2009, p. 73). To conclude, two philosophical approaches are proposed by Styles and Ambler (1996) that attempt to define a brand. In the first approach known as the product-plus approach, the brand is considered as an identifier, meaning that branding is essentially viewed as the final process in the new product development. The second approach, on the other hand, known as the holistic perspective, focuses on the brand itself; the marketing mix is customized to the needs and wants of predetermined target groups (Wood, 2000, p. 665).

\subsection{The Origins and Evolution of Branding}

In contempt of the crucial role branding plays in marketing, it is worth spending some time to briefly analyze the branding phenomenon and how it entered the discourse of marketing theory and research. Bastos and Levy (2012) explain it as:

"... the evolution of the brand from a simple entity with limited application and whose creation, interpretation, and control are mostly enacted by one actor (i.e. its creator), to the brand as a complex entity that is multi-dimensional and multi-functional, and that receives influences from a variety of actors (e.g. the brand manager, the consumer, the media, the marketing researcher, technology" (2012:347, italics added).

Even though the historical roots of branding may be traced back to the late 19th century with the introduction of various consumer products such as Gillette and Quaker Oats (as cited in Blain, et. al., 2005, p. 328), the word "brand" itself is centuries old, appearing back in the late fifth century A.D. Although old as a concept, as Ciardi and Williams put it "... words survive, just as do stones of an ancient ruin, falling out of the original pattern to be used again in a new context" (cited in Stern, 2006, p. 217). Figure 1 provides a roadmap to the evolution of the 'brand' as a concept (Pereira, etl.al, 2012, p. 83). As it can be clearly observed from the Figure, the word "brand" has been around for more or less 15 centuries before it approached Marketing in 1922. According to Stern (2006), the term 'brand' entered marketing in 1922 as a compound expression and meant a trade or proprietary name. Relatedly, Stern the author highlights, "The survival of brand is a signal of its vitality, for it is one of the most ancient words in English" (2006:217). As a matter of fact, the term 'brand' was first found in the Germanic languages; to then expand into Old English (Anglo-Saxon), in which it emerged as a noun [in the epic poem Beowulf] and as a verb [in Wycliffe's religious tract An Apology for Llollard Doctrines] (as cited in Stern, 2006, p. 217). 


\begin{tabular}{|c|c|c|c|c|c|c|c|c|c|}
\hline 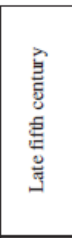 & 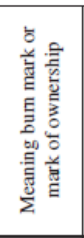 & & 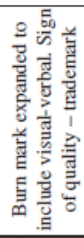 & & 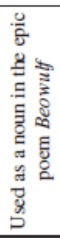 & & 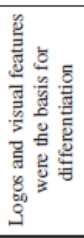 & & 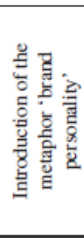 \\
\hline $\begin{array}{l}\text { Late } 5^{\text {th }} \\
\text { century }\end{array}$ & $\begin{array}{c}15^{\text {th }} \\
\text { century }\end{array}$ & 1842 & $\begin{array}{c}\text { Over the } \\
1^{\text {th }} \\
\text { century }\end{array}$ & 1922 & 1950 & 1958 & 1960 & 1976 & $1980^{\circ}$ \\
\hline 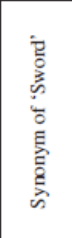 & & 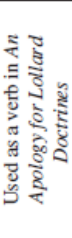 & & 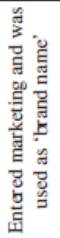 & & 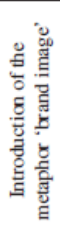 & & 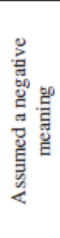 & \\
\hline
\end{tabular}

Figure 1. The Evolution of 'Brand' as a concept

Moreover, because the word can be used as either a verb or a noun, another classification flourishes; and that is the classification of the word 'brand' as either an entity or a process. In this respect, as a noun it might refer to entities such as people, places, things and ideas, whereas as a verb it might refer to certain processes in which the firm engages with the purpose of giving meaning to products and services. Such processes include naming the product, targeting and positioning it (Stern, 2006, p. 219).

Referring back to Figure 1, the word 'brand' was used as a synonym for the word 'sword', found in the war and weapons vocabulary of early English poetry, which resurrects in modern connotative marketing metaphors with concepts such as 'battle of brands', 'marketing warfare' and 'killer brands'. Further, as Stern highlights, “... from the etymological perspective, marketing research is better served by understanding how a word formerly defined as a sword has come to signify an implement in contemporary marketing battles for consumer dollars" (2006:219). To those ends, we might agree on the fact that in addition to the literal meaning of the word, there is also a connotative meaning of mental associations in metaphors like 'brand image', introduced first by Mayer in 1958, defined as "the impression of a product in the mind of the potential users and consumers" (Pereira, et.al., 2012, p. 83).

From a review of the various definitions of the term, it is revealed that 'brand' is an ambivalent construct, with both a positive and a negative meaning. To the same extent, Bastos and Levy, stress that, "as a form of marking, branding is richly ramified by application to oneself, to other people, and to property; it takes both material and metaphorical forms; and is perceived either positively or negatively" (2012:349). These simultaneously conflicting feelings in the term emerge from the Old Germanic "brinn-an", meaning "to burn". Burning as a mark of identification, and ownership is considered as a positive association. As Bastos and Levy point out in their account, "marking the skin has a long history of serving various cosmetic, medicinal, social, psychological, political, and cultural purposes", and burning as a form of marking has, according to the authors, a very powerful message to disseminate (2012:351). As such, fire is seen as a source of life, because people could use it to cook and keep themselves warm, and because it portrays people who hold on tight to their ideas and feelings. In addition to the positive association, however, there is also a negative association to the brand as a burn mark, ". $\ldots$ dating back to its use as a sign that communicates the idea of disgrace stamped on something odious" (Stern, 2006, p. 219).

Traveling from one era to another, we finally arrive at the first most solid approach of the word to modern Marketing, dating in 1960, according to which brands are linked to some visual and verbal representations. The definition of the American Marketing Association, a well-known one, despite its controversies to our days, is quoted somewhere earlier on the paper. By 1980s there appears to exist a more comprehensive view on the concept of 'brand'. As Stern points out, "... in the world, brand denotes a name or mark that is associated with a product; in the mind, it denotes a 
mental representation, an idea, or a consumer's perception of psychological meanings" (2006:219). In a similar vein, Meenaghan throws light upon the expanded nature of the concept by analysing:

"At a more emotional/symbolic level a prime function of advertising is to achieve for a brand a particular personality or character in the perception of its market. This is achieved by imbuing the brand with specific associations or values. A particular feature of all great brands is their association with specific values, both functional and symbolic." (1995:27)

\title{
3.3 Place branding and destination branding as its tourism-related subarea
}

Although the concept of branding has its roots back in the 1940s (Guest, 1942), the first journals that have tackled tourism destination branding did not flourish until 1998, with the study of Pritchard and Morgan (1998), in which the concepts of 'branding' and 'destination image' were integrated together. The recent appearance of the 'destination branding' articles in the academic arena gives us strong reasons to suspect that this concept is in its infancy.

Further, from the review of the literature it is found out that the number of published destination branding articles have substantially grown through the years. As such, there were fiftyeight destination branding articles within this range (Saraniemi \& Ahonen, 2008). Twenty seven of them were set on a country/state context, following city (10) and region (10). From the literature review conducted it was revealed that destination branding has embraced various frames from marketing literature, more specifically from the branding literature. Some of the most well-known frameworks employed and tested in the destination context are Aaker's (1992) brand personality scale, and de Chernatony's and McWilliam's Brand Box model (as cited in Saraniemi \& Ahonen, 2008, p. 439). Moreover, 'country of origin studies' (Papadopoulos, 2004, p. 40) and 'brand loyalty' are combined to destination branding studies. 'Customer-based brand equity' and 'communicating the brand' have also been transferred in the destination context. When it comes to agreeing on a definition of 'destination branding' no matter how fragmented the area of study is and disregarding the many controversies that exist in the field, this examination of the literature found some very insightful definitions that are more holistic in nature than just logo development. As such, Ritchie and Ritchie (1998) have proposed the following definition of 'destination branding' appreciating the work of Aaker (1991), who has developed 'identification' and 'differentiation' as the core concepts of branding,

\begin{abstract}
"... a name, symbol, logo, word mark or other graphic that both identifies and differentiates the destination; furthermore, it conveys the promise of a memorable travel experience that is uniquely associated with the destination; it also serves to consolidate and reinforce the recollection of pleasurable memories of the destination experience"(1998:103; as cited in Blain, Levy and Ritchie, 2005, p. 329)
\end{abstract}

Two other concepts are however added to Aaker's (1991) framework, being them 'experience' and 'promise'. Indeed, research indicates that although visitors buy individual tourism services, they tend to seek value from the whole experience, so it can be agreed on the premise that visitors are actually buying the entire visitor experience. In such a vein, Hankinson (2009) notes that, "places that want to flourish must deliver distinctive, compelling, memorable and rewarding experiences to their target consumers" (as cited in Hanna and Rowley, 2012, p. 104). Similarly, but from another perspective Anholt (2010) argues that experience is the key to place branding. According to the author, "Marketing communications create interest, which results in sales, which results in consumer experience of the product, which, if satisfactory and shared, results in brand equity" (2010:10). In addition to consumer experience, the 'promise' of a brand is just as valuable for destinations as it is for other service organizations (Blain, Levy and Ritchie, 2005, p. 329). Baker (2007), on the other hand, provides an amalgamation of the two concepts by stressing that each experience has a crucial role in defining and delivering the promise that is innate within the brand (as cited in Hanna and Rowley, 2012, p. 104).

Along with Aaker (1991), Ritchie and Ritchie (1998), and Kerr (2006), an alternative framework is proposed by Hankinson (2004). This framework relies on the concept of brand 
networks, where the relationship between four different components makes up the core brand. Based on this model, place is developed as "relational brand networks", and it is represented by 'place brand' as the core brand, and four categories of brand relationships, namely consumer relationships, primary service relationships, brand infrastructure, and media relationships. Adding to the identification of the concept of brand networks, this model aims also at stressing the importance of brand reality and brand experience to consumers. Despite the precious input of various studies (Morgan and Pritchard, 1998; Hankinson, 2004; Trueman et al., 2004; Merrilees et al., 2005; Balakrishnan, 2009; Pike, 2008) in clarifying concepts like 'destination branding' or 'place branding' and their position in the marketing literature, the line between these concepts seems to be blurred. In this respect, it is argued and supported among scholars that a 'destination brand' represents the tourism dimension of a place, falling in this way under the 'place brand' umbrella (Hanna and Rowley, 2012, p. 104). Akin to the lack of consensus as to the definition of a 'brand', there seems to reside little unanimity in the definition of 'place branding', as well (Kavaratzis and Ashworth, 2005, p. 185). Zenker and Braun (2010) relying on the aforementioned contributions of Aaker (1991), Ritchie and Ritchie (1998), and Kerr (2006), define 'place brand' as "a network of associations in the consumers' mind based on the visual, verbal, and behavioural expression of a place, which is embodied through the aims, communication, values, and the general culture of the place's stakeholders and the overall place design" (as cited in Hanna and Rowley, 2012, p. 104; italics added). They augment the contribution put forth in explaining a 'destination brand' by widening the focus from the image creation to an appreciation of the process of executing the promised experience. Further, the Journal of Place Branding and Public Diplomacy propose another definition echoing the economic, social, political and cultural development of place. As such, they define 'place branding' as "applying brand strategy and other marketing techniques and disciplines to the economic, social, political and cultural development of cities, regions and countries" (Hanna and Rowley, 2012, p. 104).

Further to the foregoing, 'place branding', as a wider umbrella of its tourism-related subarea, destination branding, demonstrates a long history in itself before it entered the mainstream marketing. As Kavaratzis and Ashworth (2008) explain, although what was then called 'place promotion' entered in the academic literature in the 1970s, the literatures presented were isolated from each-other, and largely disconnected from mainstream marketing. In a similar vein, Hankinson emphasizes that, "Classical branding theory, with its roots in product marketing, is, however, in its infancy and the application of branding to the more specialist area of marketing is even less developed" (2004:110). Only by the end of the twentieth century did, however, emerge the first 'place branding' articles published in the mainstream branding literature (Kavaratzis, 2004; Pike, 2008; as cited in Hankinson, 2010, p. 301). More specifically, as we can observe from the developments underlined in Figure 3 above, the modern practice of branding began in the United States in the late 1800s and early 1900s, with the establishment of some of the most famous brands, like Coca-Cola, Colgate and Heinz, that we enjoy even today. Only in the 1950s, was however noticed a shift of focus from the technical aspect of the product to the image of the brand, concept culminated in the studies of Gardner and Levy, 1955; and Boulding, 1956. Place branding activities which began mainly in the United States in the mid-to-late 1800s, and which focused on 'place promotion' and 'place selling' rather than on 'place branding', derived largely from two domains, urban policy and tourism.

The deepening of the mainstream branding domain with the emergence of concepts such as brand endorsement, brand extensions, brand equity, brand architecture, and brand identity, has in turn been considered as a response to changes In the business environment (Knox and Bickerton, 2003, p. 1001). 


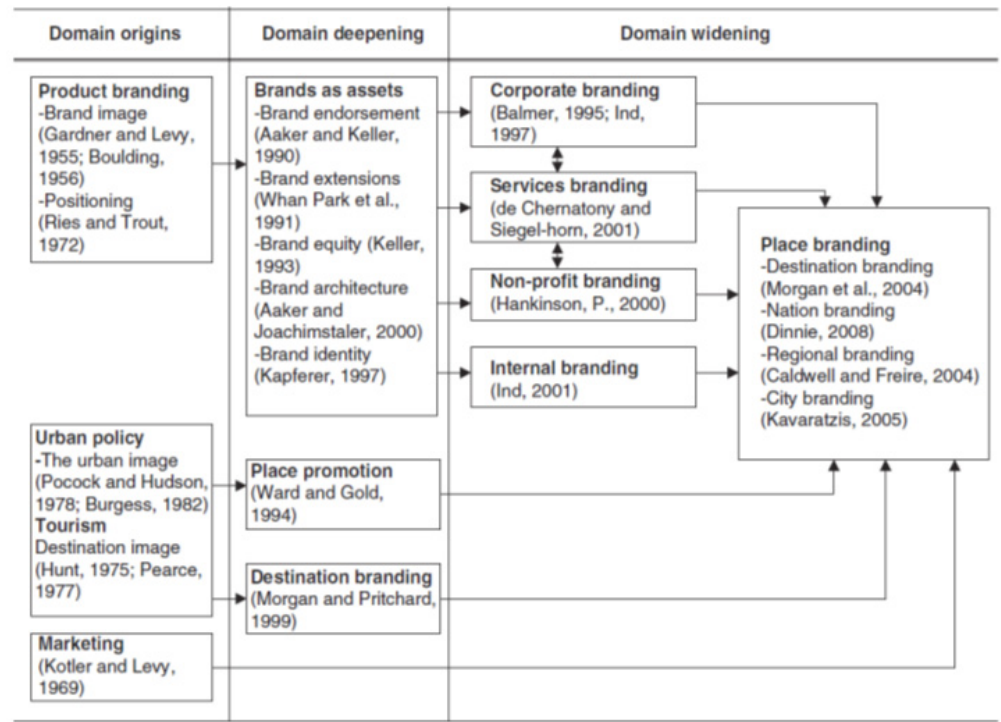

Figure 2. The development of the mainstream and place branding domains

The refocusing of branding on the organizations rather than on product branding has not only led to the developments in corporate branding, but most importantly it served as a trampoline to the embracing of branding by non-manufacturing organizations (Hankinson, 2012, p. 304). As a matter of fact, several studies (Rainisto, 2003; Kavaratzis, 2004; Trueman, et.al, 2004; Hankinson, 2007) suggest that because place branding shares various characteristics with corporate branding, the latter provides a vital contribution to place branding theory. As a result of the developments in the field, is thus, argued that "a richer and more useful theory of place branding is emerging" (Hankinson, 2007, p. 246), making out of it a 'hot topic' of research. In this respect, various scholars and commentators stress the relevance of the 'metaphor of place as corporate brand' (Anholt, 2002; as cited on Kavaratzis, 2007, p. 29), and further elaborate on the similarities between the two. In a similar vein, Kerr advocates, “... given the widespread acceptance of the similarities between the corporate brand and the location brand, researchers and practitioners in place branding have the opportunity to draw from the existing models of the corporate brand and to develop a model to reflect the key components of, and relationships within, the location brand architecture and portfolio" (2006:281). But what are some of the most cited similarities between corporate branding and place branding? "... city branding and corporate branding are similar in that they are dissimilar to product branding" argues Kavaratzis (2009:29). Further, both types of brands need to reflect and be reflected by a set of sub brands and consumer experiences (Hankinson, 2007 , p. 246), they both have multidisciplinary roots, both address multiple groups of stakeholders, both have a high level of intangibility and complexity, both deal with multiple identities, and both need a long-term development (Kavaratzis, 2009, p. 29).

To conclude, a corporate brand is the visual, verbal and behavioral expression of an organization's unique business model, which radiates through the company's mission, core values, culture and overall design (Knox and Bickerton, 2003). This definition of corporate branding is thus adapted to the context of place branding, accounting in the mean time for the brand as a network of associations in the consumer's minds (Keller, 1993; Hankinson, 2004; Keller and Lehmann, 2006), and producing the following definition of 'place branding',

"...a network of associations in the consumers' mind based on the visual, verbal, and behavioural expression of a place, which is embodied through the aims, communication, values, and the general culture of the place's stakeholders and the overall place design" (Zenker and Braun, 2010, p. 3). 


\subsection{City Branding}

In our days, the branding of places and more specifically of cities, has gained an extraordinary momentum among city officials (Anholt, 2010). As such, place marketers are striving to settle the city as a brand, with the purpose of promoting to existing and potential target groups; and differentiate themselves from each other, to assert their individuality in pursuit of various economic, political or socio-psychological objectives" (Kavaratzis and Ashworth, 2005, p. 183). Living in a world where competition is fierce, it is about time to start thinking about finding new ways to improve the image of the city with the purpose of attracting visitors. In this respect, Kotler et al., advocate that many cities and towns are "dying or chronically depressed", others can experience "boom and bust characteristics", while "favoured few" enjoy continuous and strong growth (2003:34).

Because city officials are becoming aware of the strategic importance of branding a destination, the average per capita of city marketing budget allocated has reached promising numbers. From a study conducted with 28 responses from 12 different countries included in the Eurocities Questionnaire in 2005, the average per capita city marketing budget allocated for city branding was $€ 400,000$ /city, ranging from $£ 130,000$ to $€ 10$ million per year (Seisdedos, 2006; cited in Lucarelli and Berg, 2011, p. 9). The need to establish a successful brand for the city has been further applauded by other scholars, who rationalize upon the consequences of not having a city brand. Therefore, Trueman et al., highlights,

"Poor perceptions of a city can devaluate its image and have far reaching consequences for its future prosperity. These negative associations may reduce the likelihood of inward investment, undermine business community activities, and have a detrimental effect on the number of visitors, thereby exacerbating urban decline" (2004:317).

In contrast, devoting time, money and effort in improving consumer's perceptions on cities turns to be good business in itself. As Porter (1995) elaborates in his work, there is an urgent need to discover the untapped potential of cities, because they may be "indicators of national trends for good or for bad".

Continuing the discussion on the similarities between corporate branding and place branding, and whether city brands can be treated as corporate brands, there are various pros and cons to this issue. As such, Kavaratzis (2009) in his contribution points out that branding a city is more complex than branding corporations by making reference to Ashworth, who further argues that, "The adoption and projection of a single clear corporate identity, ethos and image will be difficult if not impossible" (2006:6). Moreover, Kavaratzis and Ashworth argue that in order to apply corporate branding to places, the place brand should be treated as "the whole entity of the place products, in order to achieve consistency of the messages sent" (2005:191). Simultaneously, it claims the connection of the city with 'stories' about it, 'stories' that need to be built in the place and then communicated out loud to all audiences (Kavaratzis, 2004, p. 71). As a result, the discussion brought forth above, demonstrates that cities can learn a lot from corporate level marketing theories, but yet there is a need to adapt such models to the specific requirements of places, and cities specifically. In this respect Kerr elaborates "... given the widespread acceptance of the similarities between the corporate brand and the location brand, researchers and practitioners in place branding have the opportunity to draw from the existing models of the corporate brand and to develop a model to reflect the key components of, and relationships within, the location brand architecture and portfolio" (2006:281).

When it comes to the definition of a 'city brand' as of almost all concepts pertained in the 'place branding' literature, consensus has not been reached in this case either. Scholars do however agree about the highly complex nature of city branding as a phenomenon, thus trying to propose some explanations of the term, rather than exact definitions of it. Table 2 provides a summary of the most cited explanations of 'city branding' in the literature. In addition to the explanations brought forth in a summarized way, an alternative insight to the issue of defining 'city brands' is, however, proposed by Mommas (2003), who states the following: 
"City branding is associated primarily with the economically inspired desire to position cities more positively in the midst of a scaled-up, more mobile and flooded market of locations and destinations. Cities have to be shaped emphatically, thematized and brought to the attention of the more mobile and less location-dependent companies, inhabitants and visitors" (cited in Kerr, 2006, p. 278).

Other contributors in the field have proposed a derivation of a 'city brand' definition from that of a 'nation brand'. As such, a nation brand has been defined as "the unique multidimensional blend of elements that provide the nation with culturally grounded differentiation and relevance for all of its target audiences" (Dinnie, 2008, p. 15; as cited in Dinnie, 2011, p.16). In this respect, Dinnie (2011) argues that by replacing the word 'nation' with that of 'city', we have a serviceable definition of a city brand.

Table 2. City branding as explained in the Academia

\begin{tabular}{|c|c|}
\hline Author/s & Concept Definition/Explanation \\
\hline $\begin{array}{l}\text { Nickerson and } \\
\text { Moisey (1999) }\end{array}$ & City branding is building up a relation between people and the image of their city \\
\hline Hall (1999) & $\begin{array}{l}\text { The essential goal of city branding is to "provide a consistent and focused communication } \\
\text { strategy" }\end{array}$ \\
\hline Cai (2002) & $\begin{array}{l}\text { City brand means to choose a consistent brand factor combination by establishing a } \\
\text { positive image in order to gain a recognition and differentiation with the city as the } \\
\text { destination. The brand factors include names, terms, signs, logos, design, symbol, } \\
\text { slogan, packing or the combination of the above; among them, name is the priority }\end{array}$ \\
\hline Rainisto (2003) & $\begin{array}{l}\text { City branding is a method to increase the attraction of the city; the essential point is to } \\
\text { establish city recognition }\end{array}$ \\
\hline $\begin{array}{l}\text { Kavaratzis } \\
(2004)\end{array}$ & $\begin{array}{l}\text { City branding is understood as the means both for achieving competitive advantage in } \\
\text { order to increase inward investment and tourism, and also for achieving community } \\
\text { development, reinforcing local identity and identification of the citizens with their city and } \\
\text { activating all social forces to avoid social exclusion and unrest }\end{array}$ \\
\hline Julier (2005) & City branding is considered an effort to create and enrich the city's qualities \\
\hline $\begin{array}{l}\text { Morgan and } \\
\text { Pritchard (2007) }\end{array}$ & $\begin{array}{l}\text { City branding is indeed more than mere promotion of place, as it is used in some cities to } \\
\text { rebuild and redefine their image }\end{array}$ \\
\hline
\end{tabular}

As to further rationalize upon the issue, because "destination branding acts as an umbrella brand for a portfolio of leisure, investment, and business tourism" (Trueman et al., 2004; cited in Balakrishnan, 2009, p. 613), considering also the focus of the research aforementioned, it is thought that for this particular to apply the definition of 'destination branding' to 'city branding'. Kavaratzis and Ashworth bring forth a very valuable analysis in this respect, when they state:

"All branding tries to endow a product with a specific and more distinctive identity, and that is, in essence, what most city marketing seeks to do for cities. A place needs to be differentiated through a unique brand identity if it wants to be, first, recognized as existing, secondly, perceived in the minds of place customers as possessing qualities superior to those of competitors and, thirdly, consumed in a manner commensurate with the objectives of the place" (2005:189; italics added).

From a review of the literature with the intention of identifying the main studies conducted on city branding from 2005 until June 2016, it was noticed that the existing literature is largely limited to studies focusing on dimensions such as, negative and positive assets (Kerr and Johnson, 2005); tangible and intangible elements (Pakerson and Saunders, 2004); physical and economic environment, culture, activities and facilities, psychological elements (Hankinson, 2004; Cheng and Taylor, 2007; Laaksonen, 2006; De Carlo et al., 2009), and logo design (Hayden and Sevin, 2012), calling for the need to bring a fresh approach to the topic. In this respect, Table 3 provides a summary of city branding studies from its inception to data. 
Table 3. Summary of city branding studies (2005-2016)

\begin{tabular}{|c|c|c|c|}
\hline Source & Year & $\begin{array}{l}\text { City/Research } \\
\text { Object }\end{array}$ & Brand Dimensions/Elements \\
\hline $\begin{array}{l}\text { Parkerson and } \\
\text { Saunders }\end{array}$ & $(2004)$ & $\begin{array}{l}\text { Birmingham } \\
\text { (UK) }\end{array}$ & $\begin{array}{l}\text { Tangible elements (culture, history, shopping } \\
\text { infrastructure, housing and business) } \\
\text { Intangible elements }\end{array}$ \\
\hline Kerr and Johnson & (2005) & $\begin{array}{c}\text { Bargo } \\
\text { (Australia) }\end{array}$ & $\begin{array}{l}\text { Positive and negative assets } \\
\text { Festivals } \\
\text { Tourist Accommodation } \\
\text { Sport/lifestyle }\end{array}$ \\
\hline Hankinson & $(2005)$ & 12 English cities & $\begin{array}{l}\text { Economic } \\
\text { Physical environment } \\
\text { Activities and facilities } \\
\text { Brand attitudes } \\
\text { People }\end{array}$ \\
\hline Laaksonenet al. & $(2006)$ & $\begin{array}{l}\text { Vaasa } \\
\text { (Finland) }\end{array}$ & $\begin{array}{l}\text { Nature } \\
\text { Industry } \\
\text { Culture } \\
\text { Built environment } \\
\text { Atmosphere }\end{array}$ \\
\hline Trueman et al. & $(2007)$ & $\begin{array}{l}\text { Bradford } \\
\text { (UK) }\end{array}$ & $\begin{array}{l}\text { Positive assets } \\
\text { Negative assets }\end{array}$ \\
\hline Cheng and Taylor & (2007) & $\begin{array}{c}\text { Almaty } \\
\text { (Kazakhstan) }\end{array}$ & $\begin{array}{l}\text { Greenness } \\
\text { Cultural and Ethnic Diversity } \\
\text { Leisure time activities }\end{array}$ \\
\hline Vanolo & $(2008)$ & $\begin{array}{l}\text { Turin } \\
\text { (Italy) }\end{array}$ & $\begin{array}{l}\text { Buzz } \\
\text { Art } \\
\text { Diversity } \\
\text { Nightlife }\end{array}$ \\
\hline Herstein and Jaffe & $(2008)$ & Holon (Israel) & $\begin{array}{l}\text { City's population aspect } \\
\text { City's physical aspects }\end{array}$ \\
\hline De Carlo et al. & (2009) & Milan (Italy) & $\begin{array}{l}\text { Brand Symbols } \\
\text { Brand Personality } \\
\text { Culture }\end{array}$ \\
\hline Vaidya et al. & (2009) & $\begin{array}{l}\text { Surat and } \\
\text { Ahmedabad } \\
\text { (India) }\end{array}$ & $\begin{array}{l}\text { Brand Personality } \\
\text { People } \\
\text { Employment and Business } \\
\text { Culture and Lifestyle }\end{array}$ \\
\hline Zenker et al. & (2009) & 15 German cities & $\begin{array}{l}\text { Job chances } \\
\text { Nature and recreation } \\
\text { Urbanity and diversity }\end{array}$ \\
\hline Baxter and Kerr & $(2010)$ & $\begin{array}{l}\text { Wollollong } \\
\text { (Australia) }\end{array}$ & $\begin{array}{l}\text { Brand Personality } \\
\text { Likes and Dislikes }\end{array}$ \\
\hline Prayag & $(2010)$ & $\begin{array}{l}\text { Cape Town } \\
\text { (South-Africa) }\end{array}$ & $\begin{array}{l}\text { Cognitive images } \\
\text { Affective images } \\
\text { Holistic images }\end{array}$ \\
\hline Clark et al. & $(2010)$ & $\begin{array}{l}\text { Athens } \\
\text { (Greece) }\end{array}$ & $\begin{array}{l}12 \text { themes (Young/Energized/ } \\
\text { Nostalgic/Alive/Liberated/ } \\
\text { Creative/Cool/Savvy/Inspired/ } \\
\text { Eclectic/Vibrant/Dynamic) }\end{array}$ \\
\hline Altinbasak and Yalcin & $(2010)$ & $\begin{array}{l}\text { Istanbul } \\
\text { (Turkey) }\end{array}$ & $\begin{array}{l}\text { Brand Image } \\
\text { Museums }\end{array}$ \\
\hline Northover & $(2010)$ & $\begin{array}{c}\text { Belfast } \\
\text { (Northern Ireland) }\end{array}$ & Brand Identity \\
\hline Kalandides & (2011) & $\begin{array}{l}\text { Bogota } \\
\text { (Colombia) }\end{array}$ & Descriptive brand image \\
\hline Hayden and Sevin & $(2012)$ & $\begin{array}{l}\text { Ankara } \\
\text { (Turkey) }\end{array}$ & $\begin{array}{l}\text { Brand Identity } \\
\text { Cultural Identity } \\
\text { Logo transformation }\end{array}$ \\
\hline Pinzaru & $(2012)$ & $\begin{array}{l}\text { Bucharest } \\
\text { (Romania) }\end{array}$ & $\begin{array}{l}\text { City Brand Hexagon Model dimensions } \\
\text { (presence/place/pre- } \\
\text { requisites/people/pulse/potential) }\end{array}$ \\
\hline Yuwo et al. & $(2013)$ & $\begin{array}{l}\text { Bandung } \\
\text { (Indonesia) }\end{array}$ & $\begin{array}{l}\text { Brand Image } \\
\text { Brand Awareness } \\
\text { Brand Quality } \\
\text { Brand Loyalty }\end{array}$ \\
\hline
\end{tabular}




\begin{tabular}{|c|c|c|c|}
\hline Zenker and Backman & (2013) & $\begin{array}{l}\text { Hamburg } \\
\text { (Germany) }\end{array}$ & $\begin{array}{l}\text { Brand Image } \\
\text { Brand Associations }\end{array}$ \\
\hline Moilanen & (2015) & 10 European Cities & $\begin{array}{l}\text { Awareness } \\
\text { Brand Identity }\end{array}$ \\
\hline Loncaric & (2014) & $\begin{array}{l}\text { SlavonskiBrod } \\
\quad \text { (Croatia) }\end{array}$ & $\begin{array}{l}\text { Brand Image } \\
\text { Brand Identity } \\
\text { Brand Positioning }\end{array}$ \\
\hline Blace et al. & (2015) & $\begin{array}{l}\text { Sibenik } \\
\text { (Croatia) }\end{array}$ & $\begin{array}{l}\text { Travel preference } \\
\text { Social network presence }\end{array}$ \\
\hline Yi-De & (2015) & $\begin{array}{l}\text { Liverpool } \\
\text { (UK) }\end{array}$ & $\begin{array}{l}\text { Brand Impressions } \\
\text { Brand Positioning }\end{array}$ \\
\hline Freire, J. & (2016) & $\begin{array}{l}\text { Cascais } \\
\text { (Portugal) }\end{array}$ & $\begin{array}{l}\text { Nationality } \\
\text { Environment }\end{array}$ \\
\hline Sou, Joey Pek, et.al & (2016) & $\begin{array}{l}\text { Macau } \\
\text { (China) }\end{array}$ & Destination Image \\
\hline Greenop, K. & (2016) & $\begin{array}{l}\text { Brisbane } \\
\text { (Australia) }\end{array}$ & $\begin{array}{l}\text { Brand Identity } \\
\text { Place Identity }\end{array}$ \\
\hline Aguilar, G., et.al & $\begin{array}{l}\text { (May/June } \\
\text { 2016) }\end{array}$ & $\begin{array}{l}\text { Granada } \\
\text { Torremolinos } \\
\text { (Spain) }\end{array}$ & Brand Personality \\
\hline
\end{tabular}

\section{Conclusion}

This account has provided a review of the main literature on the topic of destination branding, from the origins of the mainstream branding to the incorporation of destination branding under the corporate branding umbrella. Even though the historical roots of branding may be traced back to the late $19^{\text {th }}$ century with the introduction of various consumer products such as Gillette and Quaker Oats (as cited in Blain et al., 2005, p. 328), the word "brand" itself is centuries old, appearing back in the late fifth century A.D. the word "brand" has been around for more or less 15 centuries before it approached Marketing in 1922. According to Stern (2006), the term 'brand' entered marketing in 1922 as a compound expression and meant a trade or proprietary name. Traveling from one era to another, we finally arrive at the first most solid approach of the word to modern Marketing, dating in 1960 , according to which brands are linked to some visual and verbal representations.

Another concept that took a special place in this literature review was that of 'city branding'. The branding of places and more specifically of cities, has gained an extraordinary momentum among city officials (Anholt, 2010). As such, place marketers are striving to settle the city as a brand, with the purpose of promoting to existing and potential target groups; and differentiate themselves from each other, to assert their individuality in pursuit of various economic, political or socio-psychological objectives" (Kavaratzis and Ashworth, 2005, p. 183). Living in a world where competition is fierce, it is about time to start thinking about finding new ways to improve the image of the city with the purpose of attracting visitors. From the review of the literature, it can be concluded that the field of studies of destination branding in general and that of city branding specifically are still in their infancy suggesting that more studies can be conducted in these fields.

\section{References}

Aaker, D. A. (1991). Managing Brand Equity: Capitalizing on the value of a Brand Name, New York: Free Press. Aguilar, A. G., Guillen, M. J. \& Roman, N. V. (2016). Destination Brand Personality: An Application to Spanish Tourism, International Journal of Tourism Research, Vol. 18, pp. 210-219. doi: 10.1002/jtr.1997.

Anholt, S. (1999). Branding the developing world, Impact, Fall, pp. 1-22.

Anholt, S. (2010). Definitions of place branding - Working towards a resolution, Place Branding and Public Diplomacy, 6 (1): 1 - 10.

Anholt, S. (2010). Places - Identity, Image and Reputation, Palgrave Macmillan, New York, NY.

Ambler, T. (1992). Need-to-Know-Marketing, Century Business, London.

Ambler, T. and Styles, C. (1996). Brand development versus new product development: towards a process model of extension decisions, Marketing Intelligence and Planning, Vol. 14 No. 7, pp. 10-19.

American Marketing Association (AMA) (2016). Definition of Marketing. Retrieved July 2016 from https://www.ama.org/AboutAMA/Pages/Definition-of-Marketing.aspx.

Altinbasak, X., and Yalcin, x. (2010). City image and museums: the case of Istanbul, International Journal of Culture, Tourism and Hospitality Research, Vol. 4, No. 4, pp. 241-251. doi:10.1108/17506181011067628. 
Baker, B. (2007). Destination Branding for Small Cities: The Essentials for Successful Place Branding. Portland, Oregon: Creative Leap Books.

Balakrishnan, M. S. (2009). Strategic Branding of destinations: a framework, European Journal of Marketing, Vol. 43, No. 5/6, pp.611-629.

Bastos, W., and Levy, J. S. (2012). A history of the concept of branding: practice ad theory, Journal of Historical Research in Marketing, Vol. 4, No.3, pp. 347-368.

Blain, C., Levy, S.E., and Ritchie, B. (2005). Destination Branding: Insights and Practices from Destination Management Organizations. Journal of Travel Research, Vol. 43, 328-338, doi: $10.1177 / 0047287505274646$.

Blace, D., Coric, G. \& Juric, B. (2015). Branding the city of Šibenik as a sustainable tourist destination using social networks. Review of the Contemporary Business, Entrepreneurship and Economic Issue, Vol. 28, pp. 109-125.

Cai, xxx. (2002). Cooperative branding for rural destinations. Annals of Tourism Research, Vol. 29, No. 3, pp. 720-742.

Clark, D. J., Clark A. E., and Charles, E. J. (2010). Branding Smaller Destinations with Limited Budgets: The Example of Athens, Georgia, Journal of Hospitality Marketing and Management, 19:358-372.

Cheng, L.K.P. and Taylor, J.L. (2007). Branding of former soviet cities: the case of Almaty, The ICFAI University Journal of Brand Management, Vol. IV No. 4, pp. 7-13.

De Carlo, M., Canali, S., Pritchard, A. and Morgan, N. (2009). Moving Milan towards Expo: designing culture into a city brand, Journal of Place Management and Development, Vol. 2 No. 1, pp. 8-22.

De Chernatony, L. \& McDonald, M. (1992). Creating powerful brands. Oxford, Butterworth-Heinemann.

De Chernatony, L., and M. McDonald. (2001). Creating Powerful Brands in Consumer, Service and Industrial Markets. Oxford: Butterworth-Heinemann.

Doyle, P. (1994). Marketing Management and Strategy, Prentice-Hall, Englewood Cliffs, NJ, pp. 159-65.

Dinnie, K. (2004). Place branding: overview of an emerging literature, Journal of Place Branding and Public Diplomacy, Vol. 1 No. 1, pp. 106-10.

Dinnie, K. (2011). City Branding: Theory and Cases. Palgrave Macmillan, NewYork, 1sted.

Florek, M. (2005). The country brand as a new challenge for Poland, Place Branding, Vol. 1 No. 2, pp. 205-14.

Freire, J. (2016). Managing destination brand architecture- The Case of Cascais Municipality, Place Brand and Public Diplomacy, Vol. 12, No. 78. doi:10.1057/pb.2015.23.

Guest, L.P. (1942). The genesis of brand awareness, Journal of Applied Psychology, Vol.26, pp. 800-8.

Greenop, K. \& Darchen, S. (2016). Identifying 'place' in place branding: core and periphery in Brisbane's "New World City, Geo Journal, Vol. 81, No. 3, pp. 379-394.

Hankinson, G. (2001). Location branding: A study of the branding practices of 12 English cities, Journal of Brand Management, Vol.9 No. 2, pp 127-142.

Hankinson, G. (2004). Relational Network Brands: Towards a Conceptual Model of Place Brands, Journal of Vacation Marketing, 10 (2): 109-21.

Hankinson, G. (2009). Managing destination brands: Establishing a theoretical framework, Journal of Marketing Management, $25(1-2): 97-115$.

Hankinson, G. (2010b). Place branding theory: A cross-domain literature review from a marketing perspective. In Ashworth G. J., Kavaratzis M. (eds) Towards Effective Place Brand Management: Branding European Cities and Regions, pp. 15-35. Cheltenham, UK and Northampton, MA: Edward Elgar.

Hankinson, G. (2012). The measurement of brand orientation, its performance impact and the role of leadership in the context of destination branding, Journal of Marketing Management, Vol. 28, No. 7-8, pp. 974-999.

Hanna, S. and Rowley, J. (2012). Practitioners views on the essence of place brand management, Place Branding and Public Diplomacy, Vol. 8. doi:10.1057/pb.2012.5.

Hall, D. (1999). Destination Branding, Niche Marketing and National Image Projection in Central and Eastern Europe, Journal of Vacation Marketing, No. 5, pp. 227-237.

Hayden, C., and Sevin, E. (2012). The politics of meaning and the city brand: The controversy over the branding of Ankara, Place Branding and Public Diplomacy. Vol. 8, pp. 133-146.

Herstein, R. and Jaffe, E.D. (2008). The children's city - the transition from a negative to a positive city image, Place Branding and Public Diplomacy, Vol. 4 No. 1, pp. 76-84.

Jacobsen, B. (2009). Investor-based place brand equity: A theoretical framework" Journal of Place Brand Management and Development, Vol. 2, No. 1, pp.70 - 84.

Julier, G. (2005). Urban Design spaces and the Production of Aesthetic Consent, Urban Studies, Vol.42, pp.5-6, 689-888.

Kalandides, A. (2011). City marketing for Bogota: a case study in integrated place branding, Journal of Place Management and Development, Vol.4 No.3, pp.282-291.

Kavaratzis, M. (2004). From city marketing to city branding: Towards a theoretical framework for developing city brands, Journal of Place Branding, Vol.1, No.1, pp.58 - 73.

Kavaratzis, M., \& Ashworth, G. (2005). City branding: An effective assertion of identity or a transitory marketing 
trick? Journal of Place Branding, Vol.2, No.3, pp. 183-194.

Kavaratzis, M. and Ashworth, G. (2008). Place marketing: How did we get here and where are we going? Journal of Place Management and Development, Vol.1, No.2, pp.150 - 165.

Kavaratzis, M. (2009). Cities and their brands: Lessons from corporate branding, Journal of Place Branding and Public Diplomacy, Vol. 5, pp.26-37.

Kemp, E., Childers, C. Y., and Williams, K. H. (2012). Place branding: creating self-brand connections and brand advocacy, Journal of Product \& Brand Management, Vol. 21, No.7, pp. 508-515.

Keller, K.L. (1993). Conceptualizing, measuring, and managing customer-based brand equity, Journal of Marketing, Vol.57, No.122.

Keller, K. L. and Lehmann, D. (2006). Brands and Branding: Research Findings and Future Priorities, Journal of Marketing Science, Vol. 25, No. 6, pp.740-59.

Kerr, G. (2006). From destination brand to location brand, Journal of Brand Management, Vol. 13, No. 4 - 5, pp. $276-283$.

Kerr, G. and Johnson, S. (2005). A review of a brand management strategy for a small town - lessons learnt! Place Branding and Public Diplomacy, Vol. 1 No. 4, pp. 373-87.

Knox, S. and Bickerton, D. (2003). The six conventions of corporate branding, European Journal of Marketing, Vol. 37, No. $7 / 8$, pp. $998-1016$.

Konecnik, M. and Gartner, W. C. (2007). Customer-based Brand Equity for a Destination, Annals of Tourism Research, Vol. 34 No. 2, pp. 400-421.

Konecnik, M., Antoncic, B., \& Ruzzier, M., (2014). Cross-Cultural Model of Customer-Based Brand Equity for a Tourism Destination, IUP Journal of Brand Management, Vol. XI, No.1.

Kotler, P., Makens, J. C., \& Bowen, J. (2003). Marketing for Hospitality and Tourism. Upper Saddle River, N.J: Pearson Education International for Prentice Hall.

Laaksonen, P., Laaksonen, M., Borisov, P. and Halkoaho, J. (2006). Measuring image of a city: a qualitative approach with case example, Place Branding and Public Diplomacy, Vol. 2, No. 3, pp. 210-19.

Loncaric, B. (2014). Branding cities as tourist destinations: The case of Slavonski Brod, Croatia, Tourism and Hospitality Industry 2014, Congress proceedings. Trends in Tourism and Hospitality Industry.

Lucarelli, A., \& Berg, P. O. (2011). City branding: A state-of-the-art review of the research domain, Journal of Place Management and Development, Vol. 4, No. 1, pp. 9-27.

Meenaghan, T. (1995). The role of advertising in brand image development, Journal of Product \& Brand Management, Vol. 4 No. 4, pp. 23-34.

Merrilees, B., Getz, B. and O' Brien, D., (2005). Marketing stakeholder analysis: Branding the Brisbane Goodwill games, European Journal of Marketing, Vol. 39, No. 9 - 10, pp. 1066 - 1077.

Mommas, H. (2003). City Branding, NAl Publishers, Rotterdam, the Netherlands.

Morgan, N. and Pritchard, A., (1998). Tourism Promotion and Power: Creating Images, Creating Identities. Chichester: John Wiley \& Sons Ltd.

Morgan, N., Pritchard, A. and Pride, R. (2002). Destination Branding - Creating the Unique Destination Proposition. Butterworth-Heinemann, Oxford.

Morgan, N. and Pritchard, A., (2007). De-centring tourisms intellectual universe, or traversing the dialogue between change and transition. In Ateljevic, I., Pritchard, A, and Morgan, N. (eds.) The Critical Turn in Tourism Studies: Innovative Research Methodologies, pp. 11-28. Amsterdam: Elsevier.

Moilanen, T. (2015). Challenges of city branding: A comparative study of 10 European cities, Place Branding and Public Diplomacy, Vol.11, pp.216-225, doi:10.1057/pb.2015.6.

Nickerson, N. amd Moisey, R. (1999). Branding a State from Features to Positioning: Making it Simple? Journal of Vacation Marketing, Vol. 5, No. 3, pp.217-226.

Northover, J. (2010). A brand for Belfast: How can branding s city influence change?" Place Branding and Public Diplomacy, Vol. 6, No. 2, pp. 104-111. doi:10.1057/pb.2010.9.

Papadopoulos, N. (2004). Place branding: evolution, meaning and implications, Place Branding and Public Diplomacy, Vol. 1 No. 1, pp. 36-49.

Parkerson, B. and Saunders, J. (2004). City branding: can goods and services branding models be used to brand cities? Place Branding and Public Diplomacy, Vol. 1 No. 3, pp. 242-64.

Pereira, L.G., Correia, A. L., Schutz, R., (2012). Destination Branding: A Critical Overview, Journal of Quality Assurance in Hospitality \& Tourism, Vol. 13, pp. 81-102,

Pike, S. (2008). Destination Marketing An Integrated Marketing Communication Approach, ButterworthHeinemann: Elsevier Science.

Pinzaru, F. (2012). From Conjunctural urban storytelling to city branding: An Empirical Model for Bucharest, Management Research and Practice. Vol.4, No.2, pp. 33-44.

Porter M. (1995). The competitive Advantage of the Inner city, Harvard Business Review, from the May-June 1995 Issue.

Prayag, G. (2010a). Brand image assessment: international visitors' perception of Cape Town, Marketing Intelligence \& Planning, Vol. 28 No. 4, pp. 462-85. 
Pritchard, A. and Morgan, N. (1998), "Mood marketing - the new destination branding strategy: a case of Wales the brand", Journal of Vacation Marketing, Vol. 4 No. 3, pp. 215-29.

Randolph, J. (2009). A Guide to Writing the Dissertation Literature Review. Practical Assessment, Research \& Evaluation, Vol.14, No. 13. Retrieved June 2nd, 2016, from http://pareonline.net/pdf/v14n13.pdf.

Rainisto, S. (2003). Success factors of place marketing: A study of place marketing practices in Northern Europe and the United States, PhD thesis, Helsinki University of Technology, Institute of Strategy and International Business.

Ritchie, J. R. Brent, and Robin J. B. Ritchie (1998). The Branding of Tourism Destinations: Past Achievements and Future Challenges, Proceedings of the 1998 Annual Congress of the International Association of Scientific Experts in Tourism, Destination Marketing: Scopes and Limitations, edited by Peter Keller. Marrakech, Morocco: International Association of Scientific Experts in Tourism, 89-116.

Saraniemi, S. \& Ahonen, M. (2008). Destination Branding from Corporate Branding Perspective. Proceedings of the Conference on Corporate Communication 2008, June 6th - 9th, 2008, Wroxton, England: 435 - 448.

Seisdedos, G. (2006). State of the art of city marketing in European cities, Paper presented at the 42nd IsoCaRP Congress, Istanbul.

Sou, J.P., Vinnicombe, T., Leung, T., C. (2016). Rebranding Macau: Views of Cultural industry insiders. International Journal of Culture, Tourism and Hospitality Research, Vol. 10, No. 1, pp. 91-104. doi: 10.1108/IJCTHR-01-2015-0004.

Stanton, W.T., Etzel, M.J. and Walker, B.J. (1991). Fundamentals of Marketing, 9th ed., McGraw- Hill, New York, NY.

Stern, B. B. (2006). What does brand mean? Historical-analysis method and construct definition, Journal of the Academic Marketing Science, Vol. 34, No.2, pp. 216-223.

Trueman, M., Klemm, M. and Giroud, A., (2004). Can a city communicate? Bradford as a corporate brand, Corporate Communications: An International Journal, Vol. 9, No. 4, pp.317 - 330.

Vanolo, A. (2008). The image of the creative city: some reflections on urban branding in Turin, Cities, Vol. 25, No. 6, pp. 370-382. doi:10.1016/j.cities.2008.08.001.

Vaidya, R., Gandhi, P. and Aagja, J. (2009). Brand personality and perception measures of two cities: Surat and Ahmedabad, The ICFAI University Journal of Brand Management, Vol. VI No. 1, pp. 57-73.

Watkins, T. (1986). The Economics of the Brand, McGraw-Hill, London, p. 22.

Wood L. (2000). Brands and brand equity: definition and management, Journal of Management Decision, Vol. 38 , No. 9, pp.662 - 669 .

Zenker, S. (2009). Who's your target? The creative class as a target group for place branding, Journal of Place Management and Development, Vol. 2 No. 1, pp. 23-32.

Zenker, S. and Braun, E. (2010). Branding a city - a conceptual approach for place branding and place brand management, Paper presented at the 39th European Marketing Academy Conference, Copenhagen, Denmark, 1st - 4th June 2010.

Zenker, S., and Beckmann, S. C. (2013). Measuring brand image effects of flagship projects for place brands: The case of Hamburg, Journal of Brand Management, Vol.20 No.8, pp. 642-655.

Yi-De L. (2015). Major event and city branding: An evaluation of Liverpool as the 2008 European Capital of Culture, Journal of Place Management and Development, Vol. 8, No. 2, pp.147-162.

Yuwo, H., Ford, B. J. \& Purwanegara, S. M. (2013). Customer-based brand equity for a tourism destination (CBBETD): The specific case of Bandung City, Indonesia, Organizations and Markets in Emerging Economies, Vol. 4, No. 1, pp.8-22. 